\title{
Mercury Biodistribution in Rats after Chronic Exposure to Mercury Chloride
}

\author{
Mariana Z. G. Fornazier, ${ }^{a}$ Tatiani B. Nascimento, ${ }^{b}$ Vinicius B. Marques, ${ }^{b}$ \\ Tatiana D. Saint'Pierre, ${ }^{c}$ Dalton Vassalo, ${ }^{b}$ Geisamanda P. Brandão, ${ }^{a}$ \\ Leonardo dos Santos ${ }^{b}$ and Maria T. W. D. Carneiro ${ }^{*, a}$
}

\author{
${ }^{a}$ Departamento de Química, Universidade Federal do Espírito Santo, \\ Avenida Fernando Ferrari, 514, Goiabeiras, 29043-900 Vitória-ES, Brazil \\ ${ }^{b}$ Departamento de Ciências Fisiológicas, Universidade Federal de Espírito Santo, \\ Campus de Maruípe, Avenida Marechal Campos, 1468, 29043-900 Vitória-ES, Brazil \\ 'Departamento de Química, Pontifícia Universidade Católica do Rio de Janeiro, \\ Rua Marquês de São Vicente, 225, Bairro Gávea, 22453-900 Rio de Janeiro-RJ, Brazil
}

\begin{abstract}
This study aimed to evaluate the distribution of mercury in rats after controlled chronic exposure to three different doses of $\mathrm{HgCl}_{2}$ for 30 days. Samples of blood, brain, liver, testis, heart, and kidneys were collected for mercury determination. Although the rats were exposed to different doses, the Hg levels in blood were similar among the groups under study. However, the distribution of mercury in the organs have substantially differed between low and high doses. There was a significant tendency to high deposition in the liver and kidney. The deposition profile in the tissues suggests that the level of mercury remains relatively low in blood while it is deposited at preferential sites such as liver and kidney, demonstrating that, at least at the doses studied, the screening for $\mathrm{Hg}$ exposure is unreliable by blood sample analysis.
\end{abstract}

Keywords: mercury, biodistribution, intoxication, ICP-MS

\section{Introduction}

Contamination by some trace elements presents a high risk to public health due to their poor metabolization and elimination, thereby accumulating in organisms. ${ }^{1}$ Among these elements, mercury has highlighted role due to their accumulation capacity along the food chain. Mercury is a naturally occurring element in the earth's crust, in water, biota and atmosphere. However, mercury in the environment has not only natural sources, such as volcanic emissions, but also anthropogenic sources like emissions to the atmosphere from fossil fuel combustion, coal combustion and biomass burning. ${ }^{2}$ Additionally, this element is often found in water bodies due to the industrial effluents. $^{3}$

Mercury may be present in the organic or inorganic forms, being the organic species (e.g., methylmercury $\mathrm{CH}_{3} \mathrm{Hg}^{+}$) the most toxic to mammals including man. Considering that about $75-95 \%$ of the mercury in fish is $\mathrm{CH}_{3} \mathrm{Hg}^{+}$, intoxication by chronic exposures commonly

*e-mail: mariacarneiro@hotmail.com occurs through contaminated seafood and fish intake. ${ }^{4-6}$ The inorganic mercury species include elemental mercury $\left(\mathrm{Hg}^{0}\right)$, mercurous ion $\left(\mathrm{Hg}_{2}{ }^{2+}\right)$ and mercuric ion $\left(\mathrm{Hg}^{2+}\right)$. The $\mathrm{Hg}^{0}$ is poorly absorbed and has a low health risk when it is in liquid form at room temperature, but its vapor is rapidly absorbed through the lungs and may cause occupational exposure. Among the inorganic compounds, divalent mercury salts are the most important toxic forms, although the effects in human are not fully characterized. ${ }^{5-8}$

Since the late XIX century to the present, a number of studies has been done to investigate the toxic effects of mercury on the organic systems in order to determine the main mechanisms and the relationship between the level of exposure and the impacts on health. In this regard, it has been identified harmful effects to the nervous, cardiovascular renal and other systems. .,5,-13 $^{4}$

About the distribution of mercury among the organs and tissues, it was demonstrated that once organic mercury is absorbed, it is almost totally oxidized to the divalent form (inorganic mercury) in erythrocytes, liver and kidneys. ${ }^{14}$ Similarly, absorbed elemental mercury can be oxidized to mercuric form, a process that takes some 
minutes. Independent of originally exposed or internally biotransformed, mercury salt is initially distributed preferentially to the red blood cells and plasma. Then, the $\mathrm{Hg}^{2+}$ is metabolized by the liver, but it is the kidney where this element accumulates, potentially causing acute tubular necrosis. ${ }^{15}$ Although a possible concentration-dependent effect of this metal on the different organs may exist, and reference values for blood mercury levels have already been established, our group have shown adverse effects, including cardiovascular dysfunction, due to exposure at concentrations near or below those considered safe. ${ }^{16-21}$

To study the chronic effects of mercury exposure, it was previously developed a controlled model of chronic exposure to mercury chloride $\left(\mathrm{HgCl}_{2}\right)$ for 30 days in the rat. ${ }^{19}$ This protocol resulted in blood mercury concentrations of $8 \mathrm{ng} \mathrm{mL} \mathrm{mL}^{-1}(29 \mathrm{nM})$, which is similar to those found in exposed humans. ${ }^{22}$ In order to better understand the kinetics of mercury in the exposed body and considering that the toxic effects should vary with the chemical form, dose, and affected systems, this study aimed to evaluate the mercury distribution in some target organs of Wistar rats after chronic and controlled exposure to $\mathrm{HgCl}_{2}$ in different doses. In this study, it was used different $\mathrm{HgCl}_{2}$ doses than the one previously used to investigate a possible concentrationdependent effect of this metal on its distribution. ${ }^{18,19}$

\section{Experimental}

\section{Animals}

A total of 24 male Wistar rats with two months old and weighting 120 to $180 \mathrm{~g}$ were used in this study. The animals were supplied by the Central Animal Facility at the Health Sciences Center, Federal University of Espirito Santo (Vitória, ES, Brazil). They were kept in cages and exposed to $12 \mathrm{~h}$ of a light/dark cycle, under controlled temperature and humidity conditions, receiving water and standard rat chow. The care and the use of experimental animals is in accordance to the Brazilian Guidelines for the Care and Use of Animals for Scientific and Educational Purposes and the National Institutes of Health guidelines (Guide for the Care and Use of Laboratory Animals) and were approved by the Institutional Ethics Committee on Animal Use (061/2014CEUA-UFES).

\section{Experimental design}

Rats were weighed and randomly assigned to the experimental groups: (A) low dose $(n=7$, which received intramuscular injections, into the back of the thigh, of $\mathrm{HgCl}_{2} 2.172 \mu \mathrm{g} \mathrm{kg}^{-1}$ for $1^{\text {st }}$ dose, and subsequent doses of
$0.028 \mu \mathrm{g} \mathrm{kg}^{-1}$ per day to cover daily losses); (B) intermediate dose $(n=4$, which received intramuscular injections of $\mathrm{HgCl}_{2} 10.86 \mu \mathrm{g} \mathrm{kg}^{-1}$ for $1^{\text {st }}$ dose and subsequent doses of $0.140 \mu \mathrm{g} \mathrm{kg}^{-1}$ per day to cover daily losses) and (C) high dose $(n=7$, which received intramuscular injections of $\mathrm{HgCl}_{2} 21.72 \mu \mathrm{g} \mathrm{kg}^{-1}$ for $1^{\text {st }}$ dose and subsequent doses of $0.280 \mu \mathrm{g} \mathrm{kg}^{-1}$ per day to cover daily losses).

\section{Blood and organs collection}

The rats were anesthetized with urethane ethyl carbamate (1.2 $\mathrm{g} \mathrm{kg}^{-1}$ intraperitoneally), then a laparotomy was performed and blood samples $(4 \mathrm{~mL})$ were collected from the aorta artery. The kidneys, testis, and liver samples were also collected from groups A and C. After thoracotomy the heart was excised, and after the skull dissection, the brain was also collected from groups $\mathrm{A}$ and $\mathrm{C}$. All organs were stored and frozen at $-80{ }^{\circ} \mathrm{C}$ until the analysis.

\section{Mercury determination}

The samples of kidney, testis, heart and brain were dried for about $72 \mathrm{~h}$ at about $60{ }^{\circ} \mathrm{C}$, and thereafter were macerated. An acid decomposition assisted by microwave (GO Multiwave Anton-Paar, Austria) was carried out with the samples using $0.1 \mathrm{~g}$ of sample, $3 \mathrm{~mL}$ of $\mathrm{HNO}_{3} 65 \% \mathrm{~m} \mathrm{~m}^{-1}$ (analytical grade, Merck Millipore, USA), $1 \mathrm{~mL} \mathrm{H}_{2} \mathrm{O}_{2} 30 \% \mathrm{v} \mathrm{v}^{-1}$ (analytical grade, Proquimios, Rio de Janeiro, Brazil) and $4 \mathrm{~mL}$ of ultrapure water (resistivity <18.2 M $\Omega \mathrm{cm}$, PURELAB Ultra, ELGA, UK). After cooling, the solution was diluted to $15 \mathrm{~mL}$. Before the analysis, the solution was further 3:10 diluted. Rh $\left(10 \mu \mathrm{g} \mathrm{L}^{-1}\right)$ and $\mathrm{Au}\left(1 \mathrm{mg} \mathrm{L}^{-1}\right)$ were used as internal standard and to prevent memory effect, respectively. The blank sample was prepared under the same conditions as the experimental samples. For analysis of the blood, the determination of $\mathrm{Hg}$ was performed according to Palmer et al. ${ }^{23}$ i.e., $200 \mu \mathrm{L}$ of blood was diluted to $10 \mathrm{~mL}$ with Triton-X100 $0.005 \% \mathrm{v} \mathrm{v}^{-1}$ prepared in nitric acid $0.5 \% \mathrm{v} \mathrm{v}^{-1}$. Calibration was carried out using the same procedure, substituting the blood sample of exposed rat to an unexposed sample. Monoelementar solutions (SCP Science, Canada) of $\mathrm{Hg} 10 \mathrm{mg} \mathrm{L}^{-1}$, Au $1000 \mathrm{mg} \mathrm{L}^{-1}$ and $\mathrm{Rh} 10 \mathrm{mg} \mathrm{L}^{-1}$ were used. The reference material DORM 4 (fish protein, National Research Counil (NRC), Canada) was used to assess the accuracy of the analytical procedure. For the determination of mercury in the organs and blood an inductively coupled plasma mass spectrometer (ICP-MS) Nexlon 300D (PerkinElmer, USA) was used. All determinations were performed in triplicate. Table 1 shows the operational parameters for mercury determination by ICP-MS. 
Table 1. Operational parameters for mercury determination by ICP-MS

\begin{tabular}{lc}
\hline Operational condition & \\
\hline Spray chamber & baffled cyclonic \\
Nebulizer & nickel, 1.1 \\
Cones and orifice diameter / mm & 15.00 \\
Sampling depth / mm & 1550 \\
Radio frequency power / W & 1.20 \\
Ar auxiliary / $\left(\mathrm{L} \mathrm{min}^{-1}\right)$ & 16.00 \\
Ar plasma / $\left(\mathrm{L} \mathrm{min}{ }^{-1}\right)$ & 1.04 \\
Ar nebulizer / $\left(\mathrm{L} \mathrm{min}^{-1}\right)$ & 3 \\
No. replicates & 2250 \\
Integration time / ms & ${ }^{202} \mathrm{Hg},{ }^{103} \mathrm{Rh}$ \\
\hline Isotope $(\mathrm{m} / \mathrm{z})$ &
\end{tabular}

Statistical analysis

Results are presented as the mean \pm standard deviation (SD). Comparisons between groups were performed using one-way analysis of variance (ANOVA). A value of $p<0.05$ was regarded as statistically significant.

\section{Results and Discussion}

The analytical procedure reached satisfactory precision and accuracy as shown in Table 2, indicating that processing and analytical procedures were reliable.

Table 2. Analytical figures of merit obtained for $\mathrm{Hg}$ determination using ICP-MS

\begin{tabular}{lc}
\hline Merit parameter & Result \\
\hline Equation of linear regression & $\mathrm{Y}=3268.6 \mathrm{X}-2.7739$ \\
Determination coefficient $\left(\mathrm{R}^{2}\right)$ & 1.0000 \\
Limit of detection (LOD) / (ng L-1) & 6.0 \\
Limit of quantification (LOQ) & 20.0 \\
for the method / (ng L & $-1)$ \\
Limit of quantification (LOQ) & 10.0 \\
for the sample / $\left(\mathrm{ng} \mathrm{g}^{-1}\right)$ & \\
Recovery / \% & $85-99$ \\
NRC-DORM 4 $/\left(\mathrm{mg} \mathrm{kg}^{-1}\right)$ & $0.43 \pm 0.043$ \\
\hline
\end{tabular}

${ }^{a}$ Certified value for mercury in the reference sample was $0.412 \pm 0.036 \mathrm{mg} \mathrm{kg}^{-1}$ dry mass.

Mercury concentrations in blood are shown in Table 3. No statistically significant difference $(p<0.05)$ was obtained among mercury concentrations in blood of the three exposed groups despite diverse doses were used.

It is known that human intoxication by mercury occurs mainly by direct ingestion of food made from contaminated
Table 3. Concentration of mercury obtained in blood samples of rats exposed to three different doses of $\mathrm{HgCl}_{2}$. Results are expressed as mean \pm standard deviation ( $\mathrm{n}=7$ for groups $\mathrm{A}$ and $\mathrm{C}$ and $\mathrm{n}=4$ for group $\mathrm{B}$ )

\begin{tabular}{lccc}
\hline Group & \multicolumn{2}{c}{$\begin{array}{c}\text { Mercury administered / } \\
\left(\mu \mathrm{kg}^{-1} \text { body mass }\right)\end{array}$} & $\begin{array}{c}\text { Blood mercury } \\
\text { level / }\left(\mu \mathrm{g} \mathrm{L} \mathrm{L}^{-1}\right)\end{array}$ \\
\cline { 2 - 3 } & $1^{\text {st }}$ dose & Daily doses & \\
\hline A & 2.172 & 0.028 & $3.76 \pm 0.58$ \\
B & 10.86 & 0.140 & $2.83 \pm 0.85$ \\
C & 21.72 & 0.280 & $4.29 \pm 0.51$ \\
\hline
\end{tabular}

grains, fish and shellfish, which can lead to significant amounts of mercury accumulated in different body sites. In this sense, the determination of blood levels of mercury is often screened due to the health risk reported. ${ }^{24}$ According to the Department of Surveillance in Environmental Health of the Brazilian Ministry of Health, ${ }^{25}$ reference values for mercury in the blood is based on those measured in populations potentially free of exposure to this element. Thus, the reference value for mercury in non-exposed population ranges from 1 to $8 \mathrm{ng} \mathrm{mL}^{-1}$. Interestingly, in our study we found values below the mean reference value in all rats exposed to $\mathrm{HgCl}_{2}$.

After absorption (by ingestion, injection or inhalation), mercury reaches bloodstream where binds to plasma proteins, and then can be distributed and accumulated in organs and tissues such as kidneys, liver, bone marrow, gastrointestinal tract, brain, bones, among others. ${ }^{19}$ In this work, three different doses of $\mathrm{HgCl}_{2}$ were used as attack doses for each group (A: $2.172 \mu \mathrm{g} \mathrm{kg}^{-1}$, B: $10.86 \mu \mathrm{kg} \mathrm{k}^{-1}$, and C: $21.72 \mu \mathrm{g} \mathrm{kg}^{-1}$ ), followed by daily injections with smaller doses to cover losses resulting from urinary excretion and feces. The results showed that the mercury blood levels in exposed rats were not directly related with the attack dose and they were very similar.

One likely explanation would be the fact that mercury could differently deposit on body sites, including plasma proteins and blood cells, in a dependency of the exposure level and the rate of interconversion between its chemical species. In this regard, it is known that inorganic mercury is capable of binding to thiol (-SH) groups of proteins, and consequently altering enzymatic functions vital in several biochemical processes, including the buffer capacity. ${ }^{26}$ In addition, it is currently known that not only the organic mercury or elemental mercury are oxidized to inorganic form (e.g., in erythrocytes), but there could also be a biotransformation of the mercury salt to an organic form. By supposing that organic mercury is liposoluble and highly diffusible while inorganic mercury has very low liposolubility and ability to enter cell membranes, we could speculate that as the level of exposure increases, so does 
the deposition of this metal in tissues, which would make it difficult to achieve a proportional increase in blood level as a result of increased exposure. ${ }^{27}$ As a result, although blood mercury level is useful for short-term and high-level exposures, the blood mercury should not be an estimative of the body burden in chronic and low-dose of exposures because the blood level may decrease within days of exposure. In other words, blood levels of mercury did not follow a linear relationship in parallel with the exposure, since it would increase the portion that would potentially be deposited in the peripheral tissues.

It is known that mercury is deposited also in the bones for a long period of time, and a continuous exposure to small amounts would potentially increase this bone content. In fact, the bone tissue has an extensive mineral surface area that can adsorb different toxic substances and heavy metals, minimizing their effects on the remaining body. ${ }^{28,29}$ Considering that mercury can be rarely released from the bones, unless it is in organic form, such "internal" chronic source of exposure would be relevant only in high-level of contamination. Thus, although we have not determined the bone content of mercury, it was expected that mercury firstly and majorly accumulates in those sites with a higher capacity for deposition and that have greater blood flow, such as liver and kidneys, and thereafter exhibits a wider distribution through the body.

Table 4 shows the distribution of mercury through some organs and indicate a high concentration of mercury in the kidney, even at the lowest dose used, suggesting that this is one of the first sites of deposition.

Table 4. Mercury concentrations determined by ICP-MS in organs from rats exposed to low dose (group A: $2.172 \mu \mathrm{g} \mathrm{kg}^{-1}$ for $1^{\text {st }}$ dose and subsequent doses of $0.028 \mu \mathrm{g} \mathrm{kg}^{-1}$ per day to cover daily losses) and high dose (group C: $21.72 \mu \mathrm{g} \mathrm{kg}^{-1}$ for $1^{\text {st }}$ dose and subsequent doses of $0.280 \mu \mathrm{g} \mathrm{kg}^{-1}$ per day to cover daily losses) for 30 days. Results are expressed as mean \pm standard deviation $(n=7)$

\begin{tabular}{lcc}
\hline Organ & Group A / $\left(\mu \mathrm{gg}^{-1}\right)$ & Group C / $\left(\mu \mathrm{g} \mathrm{kg}^{-1}\right)$ \\
\hline Heart & $<10$ & $15.61 \pm 4.64$ \\
Brain & $<10$ & $13.92 \pm 2.03$ \\
Testis & $<10$ & $15.85 \pm 2.45$ \\
Liver & $12.15 \pm 0.37$ & $25.51 \pm 7.69$ \\
Kidney & $302 \pm 45$ & $2819 \pm 1587$ \\
\hline
\end{tabular}

The high values of mercury found in kidney are probably due to its high flow of blood with great filtration capacity. The accumulation of mercury in the kidney happens because this organ is the main route of excretion and because it is an organ where there is more blood flow. ${ }^{30}$ When comparing the concentrations obtained in the organs of rats exposed to high dose, the kidney obtained the highest levels of mercury.
Actually, the kidney is a major target organ of inorganic mercury, exhibiting both glomerular and tubular damages. Particularly the proximal convoluted tubule is a site of uptake and accumulation majorly by luminal uptake of cysteinecombined mercury (Cys-S-Hg-S-Cys) through amino acid transporters and by basolateral uptake through organic anion transporters. ${ }^{31}$ Clinical reports and experimental studies have shown that inorganic mercury damages the renal system by altering glomerular filtration rate and inducing tubular necrosis. ${ }^{32,33}$ As a result, the clinical scenario includes polyuria and proteinuria, and in severe cases an evolution to nephritic syndrome associated with hematuria and anuria. ${ }^{34}$ Interestingly, the mercury concentration observed in the kidneys extracted from the group treated with the dose of $21.72 \mu \mathrm{g} \mathrm{kg}^{-1}$ was 10 times higher than that of the group injected with the dose of $2.172 \mu \mathrm{g} \mathrm{kg}^{-1}$, which suggests, differently from the other studied sites, a proportionality between the level of exposure and the concentrations determined by our analysis.

Compatible with our suggestion, at the lowest dose only the liver and kidney showed detectable levels of mercury, and it was not possible to quantify mercury in the remaining organs because the concentrations were below the limit of quantification (LOQ). However, at the higher dose, even though the blood concentration was close to the lower dose, it was possible to determine an accumulation of mercury in all organs studied. In this condition, the second target site of accumulation was the liver, followed by the testicles, heart and brain. It is stated that the liver accumulates this element due to its high metabolizing role: lysosomes containing acid hydrolases that can uptake both inorganic and organic mercury forms; the glutathione (GSH) synthesized in the liver binds to $\mathrm{Hg}^{2+}$ and is excreted via bile as a $\mathrm{Hg}^{2+}-\mathrm{GSH}$ compound. ${ }^{35,36}$ In the liver, similar to that occurring in the blood and other sites, the mercury forms stable complexes with sulfhydryl-cysteine groups of proteins, thereby damaging thiol-related enzymes enrolled in anti-oxidant function, immune response, protein synthesis and energy production. ${ }^{37,38}$ In fact, there is a significant increase in lipid peroxidation levels in liver along with accumulation of mercury, associated with reduction in superoxide dismutase and alkaline phosphatase and increase in lactate dehydrogenase activities, and altered histomorphology of the liver parenchyma. ${ }^{39}$ At the same time, mercury exposure also stimulates the kidney and the liver to induce stress proteins that scavenge sulfhydryl reactive metals that enter the cells, which affords partial protection against mercury toxicity in the rest of the body. ${ }^{39,40}$ Thus, the kidneys and liver would be capable of sequestering mercury and preventing accumulation and toxic effects of mercury in other sites including the blood. Similar results for other 
toxic metals, like $\mathrm{Pb}$ and $\mathrm{Cd}$, were also reported indicating a preferable accumulation in the liver and kidney. ${ }^{41-43}$

Although in the present study a highly sensitive methodology was used, it was possible to quantify mercury in the heart only from the high-dose rats. Actually, several studies indicate a relation of the mercury with the development of cardiovascular diseases, and mercury intoxication is associated with episodes of myocardial infarction, arterial hypertension, atherosclerosis and coronary artery disease. ${ }^{20,44}$ Notwithstanding, our group have previously described cardiac dysfunction even in those rats chronically injected with lower doses. ${ }^{11,20}$ The reason for this inconsistency between the evidence of cardiac dysfunction even at doses that do not lead to detectable accumulation in the heart has yet to be studied.

Regarding the male reproductive system, there are few studies on the damage by inorganic mercury. According to the works of Martinez et al., ${ }^{45-47}$ intramuscular injections of mercury chloride for 30 and 60 days in a low-dose regimen induced reproductive dysfunction characterized by impaired sperm quality, hormonal dysfunction and associated with increased oxidative stress on male reproductive system of rats. Studies in mice treated using oral administration of mercury chloride also evidenced a dose-dependent adverse effects on male rat reproduction endpoints including infertility and, in female rats, disruption of implantation of the ovum into the uterus and fetal viability. ${ }^{48,49}$

Among the evaluated sites, a lower concentration of mercury was found in the brain of rats chronically exposed to the higher dose (group C). Concerning this, it was used to be consensual that $\mathrm{Hg}^{2+}$ are not lipid soluble, thereby it should not readily cross the blood-brain barrier. In fact, the brain concentration of mercury does not correlate with the blood values..$^{50}$ However, some authors ${ }^{51}$ suggest the existence of a possible alternative route to the deposition of inorganic mercury in the brain, either as a substrate for amino acid transporters when bound to cysteine, or as endogenously transformed organic mercury. This can be verified in some studies that point to the possibility of biotransformation of inorganic mercury. ${ }^{52}$ Thus, we could speculate that once the biotransformed organic mercury reaches the brain tissue, it was oxidized to inorganic mercury, bound strongly to selenium or SH-groups, and thereby retained. This could explain why the half-life of mercury in the brain is such longer (estimated to be approximately 20 years) when compared to overall body half-life (between 30 and 60 days). ${ }^{15}$

\section{Conclusions}

The results reached in this work indicate that mercury is preferentially deposited in kidneys and liver. This preferential deposition implies in low mercury levels in blood, even when higher doses of exposure are used. Therefore, it is important to emphasize that blood does not reflect the actual level of exposure of mercury demonstrating that, at least at the doses studied, the screening for $\mathrm{Hg}$ exposure is not reliable by blood sample analysis.

\section{Acknowledgments}

The authors are grateful to FAPES (Fundação de Amparo à Pesquisa do Espírito Santo), CAPES (Coordenação de Aperfeiçoamento de Pessoal de Nível Superior), $\mathrm{CNPq}$ (Conselho Nacional de Desenvolvimento Científico e Tecnológico) and LabPetro/UFES (Laboratório de Pesquisa e Desenvolvimento de Metodologias para Análise de Petróleo) for supporting this study.

\section{References}

1. Agrawal, S.; Flora, G.; Bhatnagar, P.; Flora, S. J. S.; Cell. Mol. Biol. 2014, 60, 13.

2. Martinez-Finley, E. J.; Aschner, M.; Curr. Environ. Health Rep. 2014, $1,163$.

3. Pozebon, D.; Ressler, V. L. D.; Curtius, A. J.; Quim. Nova 1999, 22,838

4. Gochfeld, M.; Ecotoxicol. Environ. Saf. 2003, 56, 174.

5. Wiggers, G. A.; Peçanha, F. M.; Briones, A. M.; Pérez-Girón, J. V.; Miguel, M.; Vassallo, D. V.; Cachofeiro, V.; Alonso, M. J.; Salaices, M.; Am. J. Physiol.: Heart Circ. Physiol. 2008, 295, 1033.

6. Lohren, H.; Blagojevic, L.; Fitkau, R.; Ebert, F.; Schildknecht, S.; Leist, M.; Schwerdtle, T.; J. Trace Elem. Med. Biol. 2015, 32, 200.

7. Bernhof, R. A.; J. Environ. Public Health 2008, 2012, 1.

8. Grigoletto, J. C.; Oliveira, A. S.; Muñoz, S. I. S.; Alberguini, L. B. A.; Takayanagui, A. M. M.; Ciênc. Saúde Coletiva 2008, $13,533$.

9. Bakir, F.; Damluji, S. F.; Amin-Zaki, L.; Murtadha, M.; Khalidi, A.; Al-Rawi, N. Y.; Tikriti, S.; Dahahir, H. I.; Clarkson, T. W.; Smith, J. C.; Doherty, R. A.; Science 1973, 181, 230.

10. Dias, D.; Bessa, J.; Guimarães, S.; Soares, M. E.; Bastos, M. L.; Teixeira, H. M.; Forensic Sci. Int. 2016, 259, e20.

11. Simões, M. R.; Azevedo, B. F.; Fiorim, J.; Freire, D. D.; Covre, E. P.; Vassalo, D. V.; dos Santos, L.; Clin. Exp. Pharmacol. 2016, 43, 1038 .

12. Azevedo, B. F.; Simões, M. R.; Fiorim, J.; Botelho, T.; Angeli, J. K.; Vieira, J. V. A.; Alonso, M. J.; Salaices, M.; dos Santos, L.; Vassallo, D. V.; Clin. Exp. Phamacol. Physiol. 2016, 43, 712 . 
13. Zalups, R. K.; Pharmacol. Rev. 2000, 52, 113.

14. Hong, Y. S.; Kim, Y. M.; Lee, K. E; J. Prev. Med. Public Health 2012, 45, 353.

15. Dart, R. C.; Sullivan, J. B. In Medical Toxicology, $3^{\text {rd }}$ ed.; Dart, R. C., ed.; Lippincott Williams \& Wilkins: Philadelphia, United States, 2004, p. 1437-1448.

16. National Research Council; Toxicological Effects of Methylmercury; The National Academies Press: Washington, DC, United States, 2000.

17. Rice, D. C.; Environ. Res. 2004, 95, 406.

18. Wiggers, G. A.; Stefanon, I.; Padilha, A. S.; Peçanha, F. M.; Vassallo, D. V.; Oliveira, E. M.; Comp. Biochem. Physiol., Part C: Toxicol. Pharmacol. 2008, 147, 252.

19. Wiggers, G. A.; Peçanha, F. M.; Briones, A. M.; Pérez-Girón, J. V.; Miguel, M.; Vassalo, D. V.; Cachofeiro, V.; Alonso, M. J.; Salaices, M.; Am. J. Physiol.: Heart Circ. Physiol. 2008, 295, H1033.

20. Furieri, L. B.; Galán, M.; Avendaño, M. S.; Garcia-Redondo, A. B.; Aquado, A.; Martínez, S.; Cachofeiro, V.; Bartolomé, M. V.; Alonso, M. J.; Vassalo, D. V.; Salaices, M.; Br. J. Pharmacol. 2011, 162, 1819.

21. Furieri L. B.; Fioresi, M.; Júnior, R. F.; Bartolomé, M. V.; Fernandes, A. A.; Cachofeiro, V.; Lahera, V.; Salaices, M.; Tefanoni, S.; Vassalo, D. V.; Toxicol. Appl. Pharmacol. 2011, 255, 193.

22. Clarkson, T. W.; Magos, L.; Myers, G. J.; N. Engl. J. Med. 2003, $349,1731$.

23. Palmer, C. D.; Lewis, M. E.; Geraghty, C. M.; Barbosa. F.; Parsons, P. J.; Spectrochim. Acta, Part B 2006, 61, 980.

24. Branco, V.; Caito, S.; Farina, M.; Rocha, J. T.; Aschner, M.; Carvalho, C.; J. Toxicol. Environ. Health, Part B 2017, 20, 119.

25. World Health Organization (WHO); International Programme on Chemical Safety; Environmental Health Criteria 118, Inorganic Mercury; WHO: Geneva, Switzerland, 1991.

26. Asano, S.; Eto, K.; Kurisaki, E.; Gunji, H.; Hiraiwa, K.; Sato, M.; Sato, H.; Hasuike, M.; Hagiwara, N.; Wakasa, H.; Pathol. Int. 2000, 50, 169.

27. Clarkson, T. W.; Vyas, J. B.; Ballatori, N.; Am. J. Ind. Med. 2007, 50, 757.

28. Loveridge, N.; J. Anim. Sci. 1999, 77, 190.

29. Hernández-Gil, I. F.-T.; Gracia, M. A. A.; Pingarrón, M. D. C.; Jerez, L. B.; Med. Oral Patol. Oral Cir. Bucal 2006, 11, E47.

30. Nascimento, E. S.; Chasin, A. A. M.; Ecotoxicologia de Mercúrio e seus Compostos; Editora Alquimia: Salvador, 2001.

31. Bridges, C. C.; Zalups, R. K.; J. Toxicol. Environ. Health, Part B 2010, 13, 385.

32. Hodgson, S.; Nieuwenhuijsen, M. J.; Elliott, P.; Jarup, L.; Am. J. Epidemiol. 2007, 165, 72.
33. Carmignani, M.; Boscolo, P.; Artese, L.; Del Rosso, G.; Porcelli, G.; Felaco, M.; Volpe, A. R.; Giuliano, G.; Br. J. Ind. Med. 1992, 49, 226.

34. Clarkson, T. W.; Magos, L.; Crit. Rev. Toxicol. 2006, 36, 609.

35. Asano, S.; Sawada, H.; Komoriva, H.; Ohva, I.; J. Toxicol. Sci. 1979, 4, 201.

36. Miura, K.; Naganuma, A.; Himeno, S.; Imura, N. In Toxicology of Metals; Goyer, R. A.; Cherian, M. G., eds.; Springer-Verlag: Berlin, 1995, p. 163-187.

37. Kumagai, Y.; Mizukado, S.; Nagafune, J.; Shinyashiki, M.; Homma-Takeda, S.; Shimojo, N.; Brain Res. 1997, 769, 178.

38. Sener, G.; Sehirli, A. O.; Ayanoglu-Dulger, G.; Pharmacol. Toxicol. 2003, 93, 290.

39. Agarwal, R.; Goel, S. K.; Chandra, R.; Behari, J. R.; Environ. Toxicol. Pharmacol. 2010, 29, 70.

40. Morcillo, M. A.; Santamaria, J.; Biometals 1996, 9, 213.

41. Sousa, R. A.; Sabarence, C. M.; Prado, G. L. P.; Metze, K.; Cadore, S.; Talanta 2013, 104, 90.

42. Oladipo, O. O.; Ayo, J. O.; Ambali, S. F; Mohammed, B.; Toxicol. Mech. Methods 2016, 26, 674.

43. Nascimento, C. R. B.; Risso, W. E.; Martinez, C. B. R.; Environ. Toxicol. Pharmacol. 2016, 48, 272.

44. Salonen, J. T.; Seppanem, K.; Lakka, T. A.; Salonen, R.; Kaplan, G. A.; Atherosclerosis 2000, 148, 265.

45. Martinez, C. S.; Torres, J. G.; Peçanha, F. M.; Anselmo-Franci, J. A.; Vassalo, D. V.; Salaices, M.; Alonso, M. J.; Wiggers, G. A.; PLoS One 2014, 9, e111202.

46. Martinez, C. S.; Escobar. A. G.; Torres, J. C.; Brum, D. S.; Santos, F. W.; Alonso, M. L.; Salaices, M.; Vassalo, D. V.; Peçanha, F. M.; Leivas, F. G.; Wiggers, G. A.; J. Toxicol. Health 2014, 77, 143.

47. Martinez, C. S.; Peçanha, F. M.; Brum, D. S.; Santos, F. W.; Franco, J. L.; Zemolin, A. P.; Anselmo-Franci, J. A.; Júnior, F. B.; Alonso, M. J.; Salaices, M.; Vassalo, D. V.; Leivas, F. G.; Wiggers, G. A.; Reprod., Fertil. Dev. 2017, 29, 1803.

48. Heath, J. C.; Abdelmageed, Y.; Braden, T. D.; Goyal, H. O.; Biomed. Biotechnol. 2012, 2012, 1.

49. Heath, J. C.; Abdelmageed, Y.; Braden, T. D.; Nichols, A. C.; Steffy, D. A.; Food Chem. Toxicol. 2009, 47, 1600.

50. Bjorkman, L.; Lundekvam, B. F.; Laegreid, T.; Bertelsen, B. I.; Morild, I.; Lilleng, P.; Lind, B.; Palm, B.; Vahter, M.; Environ. Health 2007, 6, 30.

51. Bernhoft, R. A.; J. Environ. Public Health 2012, 2012, 1.

52. Micaroni, R. C. C. M.; Bueno, M. I. M. S.; Jardim, W. F.; Quim. Nova 2000, 23, 487.

Submitted: September 25, 2017 Published online: January 5, 2018 